\title{
THE EFFECT OF SPATIAL AND TEMPORAL FACTORS ON OCCUPANTS' BLIND USE BEHAVIORS IN MULTIFAMILY RESIDENTIAL BUILDINGS
}

\author{
Hebatalla Nazmy, Ph.D. ${ }^{1}$ and Suk-Kyung Kim, Ph.D. ${ }^{2}$
}

\begin{abstract}
Existing studies show that occupants' behavior contribute to fluctuations in energy consumption of residential units within the same building configuration. Window blinds are one of the interior design elements that the occupants use to control indoor environmental conditions. The way that occupants adjust their blinds could affect the energy performance of buildings. Thus, the purpose of this research was to identify spatial and temporal explanatory variables that correlate with occupants' use of the blinds and determine whether those variables relate to building design and surrounding sites. Data were collected by observing how occupants in apartment buildings located in a multifamily residential complex adjust their blinds. Descriptive statistics were used to define the effect of floor level, window orientation, day of observation, the hour of observation, and weather conditions on the blind status. In addition, a generalized linear mixed model was used to predict the effect of floor level and window orientation on the occupants' adjustment of blinds. The results revealed that occupants' use of the blinds correlated significantly with spatial factors, such as the apartment buildings' floor level and windows' orientation. Interesting blind use patterns were related to temporal factors, such as the day and hour of observation.
\end{abstract}

\section{KEYWORDS}

blind use, occupant behavior, energy efficiency, multifamily residential design, observation studies

\section{INTRODUCTION}

The information compiled from the Energy Information Administration (EIA) (2015), the United States Environmental Protection Agency (EPA) (1998), and the Center for Climate and Energy Solutions (C2ES) (2013) shows that buildings play a huge role in global energy consumption and greenhouse gas emissions. According to the International Energy Agency (IEA, 2017), the residential sector accounts for $21 \%$ of the total United States energy consumption by end-use sector.

1. Teaching Assistant Professor, Department of Design, Housing, and Merchandising College of Education and Human Sciences, Oklahoma State University. hnazmy@okstate.edu

2. Associate Professor, Department of Interior Architecture and Built Environment, Yonsei University Corresponding Author: Suk-Kyung

Kim, kimskyu@yonsei.ac.kr 
Sustainable housing is expected to enhance indoor environmental quality without compromising energy performance (Mahdavi, 2015). Green building rating systems set criteria to enhance the indoor environment quality. They offer four strategies to improve indoor air quality, thermal comfort, lighting, and acoustics (US Green Building Council, 2013). Research has begun to look at the relationship between the built environment and humans as a complex interplay between building occupants and various physical, chemical, biological, and psychological factors.

Previous studies have shown that occupants' behavior contributed to the fluctuations in energy consumption of residential units within the same building configuration (Tam et al., 2018). Occupants adjust blinds, among other interior elements, to control the indoor environmental conditions. This adjustment can affect the energy performance of buildings. Individual characteristics, personal preferences, indoor and outdoor environmental factors influence the occupants' behavior of adjusting blinds.

Thus, the purpose of this research was to identify explanatory variables that correlate with the occupants' use of blinds and determine whether those variables are related to building design and surrounding sites. This study utilized a quantitative approach through observations in which the patterns of using blinds were analyzed in relation to the buildings site.

\section{LITERATURE REVIEW AND THEORETICAL BACKGROUND}

Two factors, technical and behavioral, contribute to achieving energy-efficient buildings. Technical performance standards have been studied extensively and consequently raised the bar for occupant behavioral factors to be more directed towards energy efficiency (Hong et al., 2015). Numerous occupant behavior models have been developed to capture dynamic occupant-building interaction based on intensive monitoring data that establish a relationship between environmental factors and targeted operation(s). However, Yan et al. (2015) argued that more studies and models are needed to represent diverse human and environmental conditions (Yan et al., 2015).

Occupant monitoring approaches can be broken into three categories: observational studies, self-reporting studies, and experimental studies. In turn, observational studies are divided into (a) occupancy and equipment use monitoring and (b) adaptive occupant behavior monitoring. Major adaptive occupant behaviors include operating windows, adjusting blinds, closing/opening doors, switching lights on and off, and adjusting thermostats (Yan et al., 2015). Three main techniques were used when observing the blinds positions, time-lapse photography for the observed building's exterior façades, sensors that measure the positions of the blinds, and walk-throughs inside the building to manually capture and record the positions of the blinds (O’Brien et al., 2013).

Most of the previous observational studies have been conducted in commercial settings. They have provided a brief description of the geometry of buildings and surrounding sites and highlighted the factors that may contribute to the occupants' behavior of adjusting blinds (O'Brien et al., 2013). For example, most studies found a correlation between the window orientation, solar gain, and occupants' adjustment of blinds to achieve thermal comfort (Rubin et al., 1978; Zhang \& Barrett, 2012). Some studies have shown that blinds oriented towards the north tend to be more open compared to those oriented towards the south to gain more solar energy (Foster \& Oreszczyn, 2001; Pigg et al., 1995; Rubin et al., 1978). It was also found that occupants of passive buildings tend to adjust their blinds to either prevent or allow the sun in, while occupants of other types of buildings rely on HVAC systems to achieve thermal comfort. 
However, other studies have reported that the occupants' use of the blinds is less dependent on short-term weather conditions compared to long-term ones (Boyce, 1980; Foster \& Oreszczyn, 2001). Instead, they adjust them weekly or monthly to balance the visual comfort and the connection with outside views (Lindsay \& Littlefair, 1992). Moreover, occupants of office buildings mentioned that the visual discomfort caused by glare was among the biggest reasons that made them close their blinds. Achieving desirable lighting conditions was a significant reason for occupants to adjust their blinds, especially when artificial lighting is turned off automatically when an adequate amount of daylight is achieved (Pigg et al., 1995; Reinhart \& Voss, 2003).

Some studies have investigated privacy as one of the factors motivating occupants to adjust blinds. Although survey participants indicated that they close their blinds for privacy concerns, most studies showed that privacy was not a significant factor in controlling blinds in office buildings (Foster \& Oreszczyn, 2001; Humbert, 2007; Reinhart \& Voss, 2003). However, site factors were rarely considered, especially in residential buildings. This leads to unrealistic and inaccurate predictions of residential buildings' energy performance.

Researchers as early as 1970s had studied the technical factors of different fenestration types and shading devices during heating and cooling seasons in residential and commercial sectors (Brambley \& Penner, 1979). From this point, other researchers have attempted to quantify the amount of energy conservation resulting from installing fenestration and shading devices in residences (Brambley et al., 1981; Dubois, 1997; Pletzer et al., 1987). However, occupant use of blinds has rarely been considered, especially in residential buildings.

The National Research Council Canada was one of the first entities to survey Canadian households' indoor climate control. This study was a 'part of a project that aimed to develop guidelines for effective solar shading of residential windows to improve buildings' energy performance and occupants' comfort (Veitch et al., 2013). This survey provided an initial understanding of the conditions that motivate occupants to adjust their shading devices. This study showed that although respondents are aware of the implications of using shading devices for energy consumption, energy consumption was not their primary reason for adjusting them. The survey reported different patterns of the use of shading devices between heating and cooling seasons. In both seasons, occupants open their shades to admit light and have a view of the outdoors during the daytime. At night, they close their shades for privacy and to avoid the darkness.

Bennet et al. (2014) indicated that occupants' use of blinds accounts for an uncertain amount of buildings' energy use. They monitored blind use in a multi-unit residential building high-rise condominium located in Ottawa, Canada. The study's duration was six days during the summer season, including typical weekdays and a weekend day. Their study revealed that occupants of residential buildings operate their blinds on a different schedule compared to office buildings. They emphasized the need for studies that focused on residential occupants' use of blinds.

Carlucci et al. (2016) investigated the influence of occupants' behaviors on buildings' energy performance. They utilized Design Builder Software to model one high-rise multifamily residential building located in Shanghai, China. Simulation results were used to identify the spatial and temporal influence of randomness on the building's energy performance. The researchers recommended incorporating detailed occupant-dependent input variables and considering spatial and temporal factors for realistic energy performance prediction.

Pereira and Ramos (2019) conducted a study focused on one compartment (i.e., a small size apartment) in a multifamily building in Porto, Portugal. The study confirmed the seasonality effect on the occupants' use of roller shutters. They observed the highest variation of the occupants' use patterns of roller shutters during the summer season. They also indicated that 
roller shutters' operation was related to the compartments' orientation and the window to wall ratio. For example, occupants used roller shutters for shading more often in the south-and east-facing fenestration, and when they had the highest window to wall ratio.

Accordingly, this research aimed to identify any significant factors that influence the residential occupants' behavior in controlling their blinds. To achieve this aim, this study observed the occupants' behavior when operating the manually controlled blinds in residential buildings to regulate their indoor environment. The study intended to identify the factors that affect occupants' behavior in operating their blinds, such as the floor level, orientation, day, time, and weather conditions. This study's ultimate goal was to guide future research about accurately modeling the development of occupants' behaviors in residential buildings.

\section{METHODOLOGY}

Three multifamily residential buildings located in Michigan, United States, were selected for this study. The state of Michigan has four seasons. It is very cold in winter and relatively warm in summer. Therefore, this location was selected to observe the occupants' behavior in operating their Venetian (horizontal) blinds in summer. The studied buildings were constructed in 2016, and each building consists of four floors above the ground. The three buildings have the same orientation, and each building includes 63 one-bedroom and two-bedroom apartment units. The one-bedroom units have two windows, and the two-bedroom units have three windows. The units facing north are overlooking the parking area, while the other units facing south are overlooking a green area. The units located on the corners of the buildings have different views depending on their location. The total number of 45 corner units have either 4 or 5 windows, depending on their layout. The window to external wall ratio is about $20 \%$ for each building. The operation of blinds of the three buildings was observed in the summer of 2017 for seven days, July 25th through the 31st, at four different times-9:00am, 12:00 pm, 3:00 pm, and 6:00 pm.

A total number of 537 windows were observed in this study. The blinds were classified as 1-closed (C); 2-almost closed (C'); 3-semi-closed/open (S); 4-half closed/open (H); 5-almost open $\left(\mathrm{O}^{\prime}\right)$; 6-open $(\mathrm{O})$. For some of the statistical procedures, the six cases were grouped into three categories: 1-almost closed \& closed; 2-semi-closed/open; half-closed/open; 3-almost open \& open (see Figure 2). An excel sheet was created and used to mark the status of the windows' blinds at each observation time-point, as Figure 3 shows. In addition, a few pictures were taken during the time of the observations to categorize the blinds' status.

FIGURE 1(A) (Left). A rendered image of the three selected multifamily residential buildings.

FIGURE 1(B) (Right). A top view image of the three selected multifamily residential buildings.

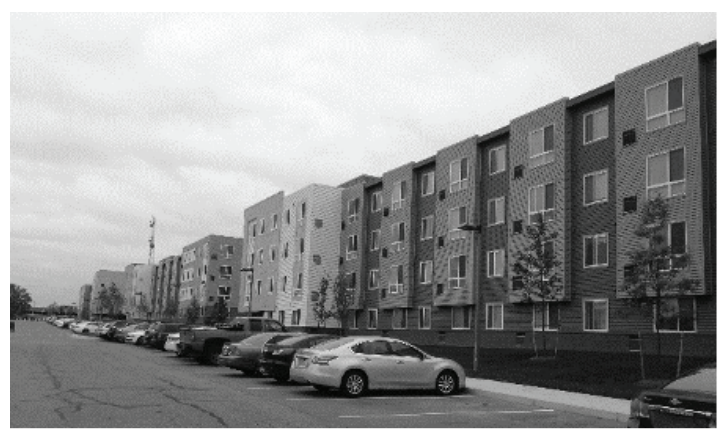

Photo credit by authors.

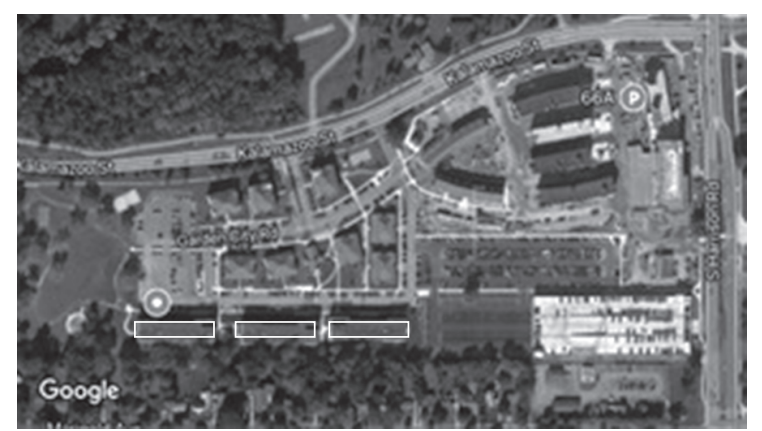

Source: https://www.google.com/map/ 
FIGURE 2. Blind Statuses as identified in the observation study.
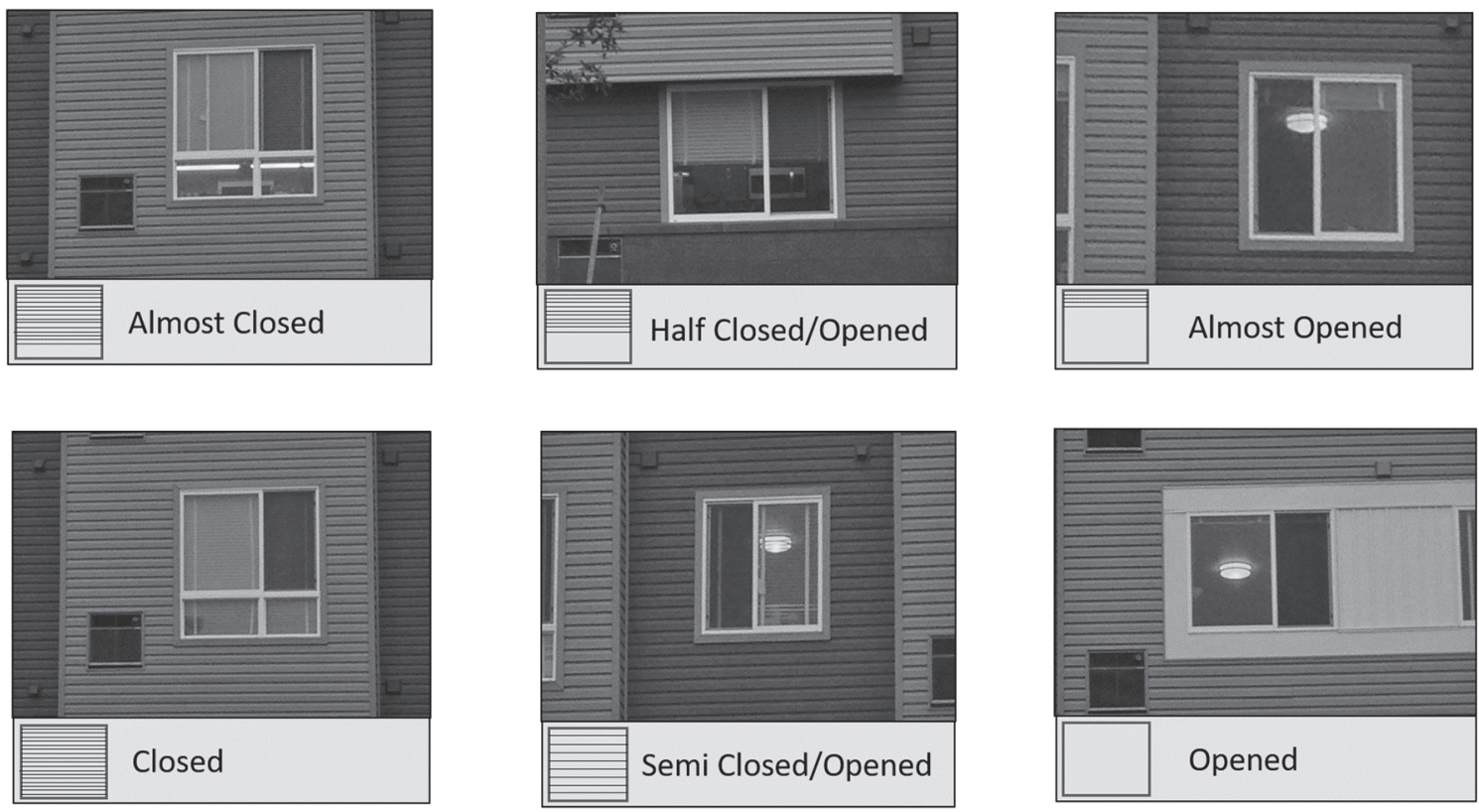

Photo credit by authors.

The blinds' status was this study's dependent variable with the six categories described previously. The independent variables were the floor level, window orientation, the day of observation, the hour of observation, and weather conditions.

FIGURE. 3. Sample of excel sheet used during the observation to mark the different status of the blinds.

\begin{tabular}{|c|c|c|c|c|c|c|c|c|c|c|c|c|c|c|c|c|c|c|c|c|}
\hline & \multicolumn{20}{|c|}{$\begin{array}{c}\text { 9:00 AM } \\
\text { Number of Windows }\end{array}$} \\
\hline & 1 & 2 & 3 & 4 & 5 & 6 & 7 & 8 & 9 & 10 & 11 & 12 & 13 & 14 & 15 & 16 & 17 & 18 & 19 & 20 \\
\hline Fourth Floor/N & $\mathrm{c}$ & $\mathrm{o}$ & c & $\mathrm{c}$ & $\mathrm{h}$ & $\mathrm{s}$ & $\mathrm{s}$ & $\mathrm{c}$ & $\mathrm{c}$ & $\mathrm{s}$ & $\mathrm{c}$ & $\mathrm{s}$ & $\mathrm{s}$ & $\mathrm{s}$ & $\mathrm{s}$ & $\mathrm{h}$ & $\mathrm{s}$ & c & $\mathrm{s}$ & $\mathrm{c}^{\prime}$ \\
\hline Third Floor/N & $c$ & $\mathrm{c}$ & $\mathrm{h}$ & 0 & 0 & $\mathrm{~s}$ & $s$ & $s$ & $\mathrm{c}$ & $\mathrm{c}$ & $\mathrm{c}$ & c & $\mathrm{c}$ & $s$ & $s$ & $s$ & $s$ & c & $\mathrm{c}$ & $\mathrm{c}^{\prime}$ \\
\hline Second Floor/N & $\mathrm{s}$ & $s$ & $\mathrm{~s}$ & c & c & c & $\mathrm{c}$ & 0 & $\circ$ & $\mathrm{s}$ & $\mathrm{s}$ & c & c & c & $\mathrm{s}$ & $\mathrm{s}$ & $s$ & $\mathrm{~s}$ & $\mathrm{~s}$ & $\mathrm{~s}$ \\
\hline First Floor/N & & & $\mathrm{s}$ & $\mathrm{s}$ & $\mathrm{s}$ & o & $\mathrm{s}$ & 0 & 0 & $\mathrm{c}$ & $\mathrm{c}$ & c & $\mathrm{c}$ & c & $\mathrm{c}$ & $\mathrm{c}$ & $\mathrm{c}$ & c & $\mathrm{s}$ & $\mathrm{s}$ \\
\hline
\end{tabular}

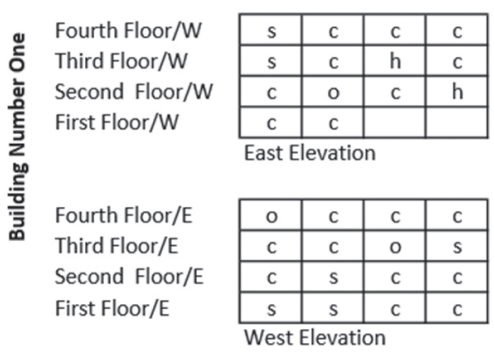

\begin{tabular}{|c|c|c|c|c|c|c|c|c|c|c|c|c|c|c|c|c|c|c|c|c|}
\hline \multirow{4}{*}{$\begin{array}{l}\text { Fourth Floor/S } \\
\text { Third Floor/S } \\
\text { Second Floor/S } \\
\text { First Floor/S }\end{array}$} & 0 & $\mathrm{~s}$ & c & $\mathrm{h}$ & $\mathrm{c}$ & $0^{\prime}$ & $\mathrm{o}^{\prime}$ & $\mathrm{c}$ & $\mathrm{c}$ & $\bar{c}$ & 0 & C & $\mathrm{c}$ & c & 0 & 0 & $\mathrm{c}$ & $\mathrm{c}$ & $\mathrm{c}$ & $\mathrm{c}$ \\
\hline & c & $\mathrm{s}$ & $\mathrm{s}$ & $\mathrm{s}$ & c & ox & $\mathrm{h}$ & $\mathrm{c}$ & 0 & 0 & 0 & c & $\mathrm{c}$ & c & 0 & $o^{\prime}$ & $\mathrm{o}^{\prime}$ & $\mathrm{s}$ & $\mathrm{s}$ & $\mathrm{s}$ \\
\hline & c & C & $\mathrm{s}$ & $\mathrm{s}$ & $\mathrm{s}$ & $0^{\prime}$ & $\mathrm{o}^{\prime}$ & $\mathrm{c}$ & $\mathrm{c}$ & ox & 0 & 0 & $\mathrm{c}$ & c & $\mathrm{s}$ & $\mathrm{o}^{\prime}$ & $\mathrm{c}$ & 0 & 0 & 0 \\
\hline & c & C & $s$ & $\mathrm{~s}$ & $s$ & $\mathrm{o}^{\prime}$ & $\mathrm{c}$ & c & $\mathrm{c}$ & $\mathrm{c}$ & $\mathrm{c}$ & c & $\mathrm{c}$ & c & $\mathrm{c}$ & c & 0 & $\mathrm{c}$ & $\mathrm{c}$ & c \\
\hline
\end{tabular}

Figure created by authors. 
TABLE 1. Comparing the frequencies of different classifications of the blinds' status by floor level.

\begin{tabular}{|c|c|c|c|c|c|c|c|c|}
\hline & \multicolumn{6}{|c|}{ Blind Status } \\
\hline & & & Closed & $\begin{array}{l}\text { Almost } \\
\text { closed }\end{array}$ & $\begin{array}{l}\text { Semi- } \\
\text { closed/ } \\
\text { opened }\end{array}$ & $\begin{array}{l}\text { Half- } \\
\text { closed/ } \\
\text { opened }\end{array}$ & $\begin{array}{l}\text { Almost } \\
\text { opened }\end{array}$ & Opened \\
\hline \multirow{8}{*}{$\begin{array}{l}\text { Floor } \\
\text { Level }\end{array}$} & \multirow{2}{*}{$\begin{array}{l}\text { First } \\
\text { floor }\end{array}$} & Count & 1626 & 70 & 1596 & 100 & 147 & 157 \\
\hline & & Percentage & $44.0 \%$ & $1.9 \%$ & $43.2 \%$ & $2.7 \%$ & $4.0 \%$ & $4.2 \%$ \\
\hline & \multirow{2}{*}{$\begin{array}{l}\text { Second } \\
\text { floor }\end{array}$} & Count & 1064 & 89 & 2081 & 134 & 240 & 424 \\
\hline & & Percentage & $26.4 \%$ & $2.2 \%$ & $51.6 \%$ & $3.3 \%$ & $6.0 \%$ & $10.5 \%$ \\
\hline & \multirow{2}{*}{$\begin{array}{l}\text { Third } \\
\text { floor }\end{array}$} & Count & 1037 & 133 & 2066 & 230 & 234 & 332 \\
\hline & & Percentage & $25.7 \%$ & $3.3 \%$ & $51.2 \%$ & $5.7 \%$ & $5.8 \%$ & $8.2 \%$ \\
\hline & \multirow{2}{*}{$\begin{array}{l}\text { Fourth } \\
\text { floor }\end{array}$} & Count & 1282 & 146 & 1854 & 259 & 231 & 260 \\
\hline & & Percentage & $31.8 \%$ & $3.6 \%$ & $46.0 \%$ & $6.4 \%$ & $5.7 \%$ & $6.4 \%$ \\
\hline \multirow{2}{*}{\multicolumn{2}{|c|}{ Total }} & Count & 5009 & 438 & 7597 & 723 & 852 & 1173 \\
\hline & & Percentage & $31.7 \%$ & $2.8 \%$ & $48.1 \%$ & $4.6 \%$ & $5.4 \%$ & $7.4 \%$ \\
\hline
\end{tabular}

Note: The highlighted numbers were addressed within the text.

\section{RESULTS}

The analysis focused on the patterns of the use of the blinds in relation to the buildings' site. The statistical analysis was conducted using IBM SPSS 22.0.

\subsection{Descriptive Analysis}

Table 1 shows the descriptive analysis describing the status of the blinds when accounting for the first independent variable, floor level. The closed blinds accounted for 31.7\%, while open blinds accounted for $7.4 \%$ of the windows across all floor levels. On the first floor, $44 \%$ of the blinds were closed, while on the second, third, and fourth floors, the closed blinds accounted for $26.4 \%, 25.7 \%$, and $31.8 \%$, respectively. On the first floor, $4.2 \%$ of the blinds were open,

FIGURE 4. Bicycle storage area marked in yellow on the google maps image next to the three selected multifamily buildings.

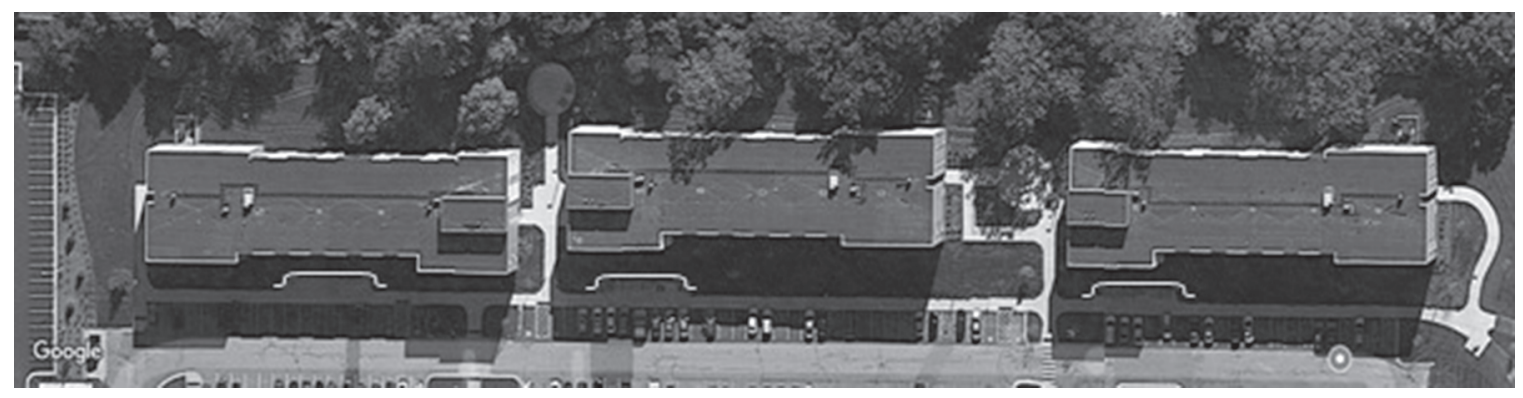

Source: https://www.google.com/maps/ 
FIGURE 5. The bicycle storage area in front of the three selected multifamily buildings.
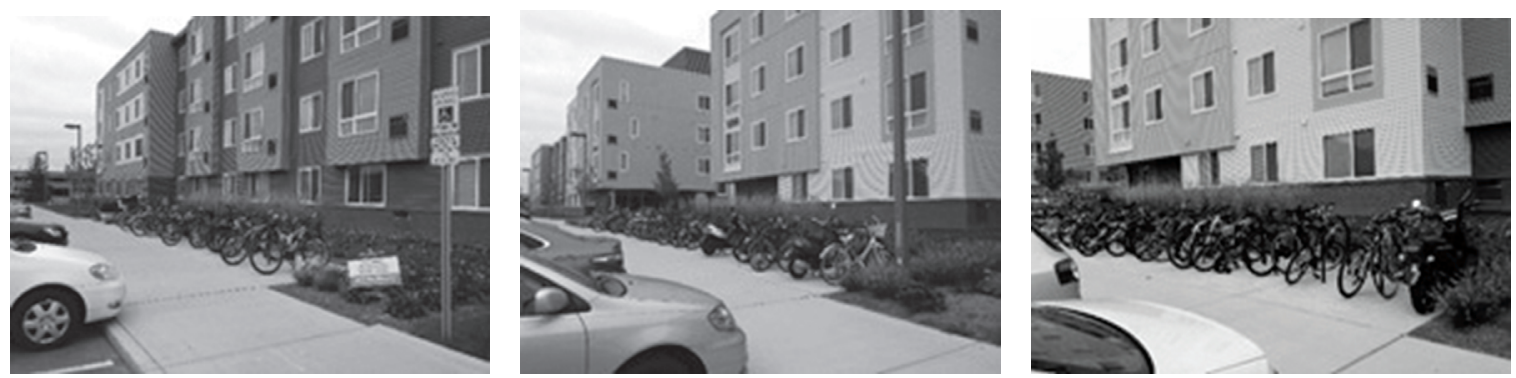

Photo credit by authors.

while on the second, third, and fourth floors, the percentages were $10.5 \%, 8.2 \%$, and $6.4 \%$, respectively. Overall, semi-closed/open blinds accounted for $48.1 \%$, which is the highest status among all other possibilities, followed by the closed and open blinds.

It is also worth mentioning that when considering the six windows on the first floor that is very close to the bicycle storage area (total number $=336$ observations), $8 \%$ of the blinds were open, $34 \%$ were closed, and 58\% were semi-closed/open. The occupants facing the bicycle storage kept their blinds mostly closed, either semi-closed or closed.

Table 2 shows the results of the descriptive analysis of the window status when accounting for the second independent variable, window orientation. The results showed that most blinds

TABLE 2. Comparing the frequencies across different blind status by window orientation.

\begin{tabular}{|c|c|c|c|c|c|c|c|c|}
\hline & \multicolumn{6}{|c|}{ Blind Status } \\
\hline & & & Closed & $\begin{array}{l}\text { Almost } \\
\text { closed }\end{array}$ & $\begin{array}{l}\text { Semi- } \\
\text { closed/ } \\
\text { opened }\end{array}$ & $\begin{array}{l}\text { Half- } \\
\text { closed/ } \\
\text { opened }\end{array}$ & $\begin{array}{l}\text { Almost } \\
\text { opened }\end{array}$ & Opened \\
\hline \multirow{8}{*}{$\begin{array}{l}\text { Window } \\
\text { Orientation }\end{array}$} & \multirow[t]{2}{*}{ North } & Count & 1735 & 162 & 4006 & 213 & 146 & 290 \\
\hline & & Percentage & $26.5 \%$ & $2.5 \%$ & $61.1 \%$ & $3.3 \%$ & $2.2 \%$ & $4.4 \%$ \\
\hline & \multirow[t]{2}{*}{ South } & Count & 2198 & 182 & 2657 & 426 & 608 & 649 \\
\hline & & Percentage & $32.7 \%$ & $2.7 \%$ & $39.5 \%$ & $6.3 \%$ & $9.0 \%$ & $9.7 \%$ \\
\hline & \multirow[t]{2}{*}{ East } & Count & 443 & 39 & 465 & 65 & 30 & 136 \\
\hline & & Percentage & $37.6 \%$ & $3.3 \%$ & $39.5 \%$ & $5.5 \%$ & $2.5 \%$ & $11.5 \%$ \\
\hline & \multirow[t]{2}{*}{ West } & Count & 633 & 55 & 469 & 19 & 68 & 98 \\
\hline & & Percentage & $47.2 \%$ & $4.1 \%$ & $34.9 \%$ & $1.4 \%$ & $5.1 \%$ & $7.3 \%$ \\
\hline \multirow{2}{*}{\multicolumn{2}{|c|}{ Total }} & Count & 5009 & 438 & 7597 & 723 & 852 & 1173 \\
\hline & & Percentage & $31.7 \%$ & $2.8 \%$ & $48.1 \%$ & $4.6 \%$ & $5.4 \%$ & $7.4 \%$ \\
\hline
\end{tabular}

Note: The highlighted numbers are addressed in the text. 
were semi-closed/open, accounting for $48.1 \%$ of the blinds' different patterns. In the north orientation, $61.1 \%$ of the blinds were semi-closed/open, while in the south orientation, this percentage was $39.5 \%$. The percentage of the open blinds in the north orientation was $4.4 \%$, while that of the south orientation was $9.7 \%$. The percentage of the closed blinds in the north orientation was $26.5 \%$, while in the south orientation, it was $32.7 \%$. The percentage of open blinds in the east orientation was $11.5 \%$, while that of the west orientation was $7.3 \%$. Finally, the percentage of the closed blinds in the east orientation was $37.6 \%$, while in the west orientation, it was $47.2 \%$. The occupants living in south-facing units tended to open the blinds more frequently compared to the occupant in north-facing units.

Table 3 shows the descriptive results for the window status when accounting for the third independent variable, which was the day of observation. The results showed that between $46-51 \%$ of the blinds remained semi-closed/open for seven days. In comparison, $29-33 \%$ of is the blinds were kept closed during the seven days. In addition, between 3.5-9\% of the blinds were open and adjusted at different levels.

TABLE 3. Comparing frequencies of different window status by day of observation.

\begin{tabular}{|c|c|c|c|c|c|c|c|c|}
\hline & & & \multicolumn{6}{|c|}{ Blind Status } \\
\hline & & & Closed & $\begin{array}{l}\text { Almost } \\
\text { closed }\end{array}$ & $\begin{array}{l}\text { Semi- } \\
\text { closed/ } \\
\text { opened }\end{array}$ & $\begin{array}{l}\text { Half- } \\
\text { closed/ } \\
\text { opened }\end{array}$ & $\begin{array}{l}\text { Almost } \\
\text { opened }\end{array}$ & Opened \\
\hline \multirow{14}{*}{$\begin{array}{l}\text { Day of } \\
\text { Observation }\end{array}$} & \multirow{2}{*}{$\begin{array}{l}\text { First } \\
\text { day }\end{array}$} & Count & 746 & 68 & 1041 & 80 & 120 & 201 \\
\hline & & Percentage & $33.1 \%$ & $3.0 \%$ & $46.1 \%$ & $3.5 \%$ & $5.3 \%$ & $8.9 \%$ \\
\hline & \multirow{2}{*}{$\begin{array}{l}\text { Second } \\
\text { day }\end{array}$} & Count & 708 & 78 & 1042 & 105 & 138 & 185 \\
\hline & & Percentage & $31.4 \%$ & $3.5 \%$ & $46.2 \%$ & $4.7 \%$ & $6.1 \%$ & $8.2 \%$ \\
\hline & \multirow{2}{*}{$\begin{array}{l}\text { Third } \\
\text { day }\end{array}$} & Count & 664 & 77 & 1128 & 100 & 111 & 176 \\
\hline & & Percentage & $29.4 \%$ & $3.4 \%$ & $50.0 \%$ & $4.4 \%$ & $4.9 \%$ & $7.8 \%$ \\
\hline & \multirow{2}{*}{$\begin{array}{l}\text { Fourth } \\
\text { day }\end{array}$} & Count & 720 & 69 & 1067 & 105 & 140 & 155 \\
\hline & & Percentage & $31.9 \%$ & $3.1 \%$ & $47.3 \%$ & $4.7 \%$ & $6.2 \%$ & $6.9 \%$ \\
\hline & \multirow{2}{*}{$\begin{array}{l}\text { Fifth } \\
\text { day }\end{array}$} & Count & 713 & 59 & 1083 & 109 & 130 & 162 \\
\hline & & Percentage & $31.6 \%$ & $2.6 \%$ & $48.0 \%$ & $4.8 \%$ & $5.8 \%$ & $7.2 \%$ \\
\hline & \multirow{2}{*}{$\begin{array}{l}\text { Sixth } \\
\text { day }\end{array}$} & Count & 735 & 47 & 1093 & 120 & 111 & 150 \\
\hline & & Percentage & $32.6 \%$ & $2.1 \%$ & $48.4 \%$ & $5.3 \%$ & $4.9 \%$ & $6.6 \%$ \\
\hline & \multirow{2}{*}{$\begin{array}{l}\text { Seventh } \\
\text { day }\end{array}$} & Count & 723 & 40 & 1143 & 104 & 102 & 144 \\
\hline & & Percentage & $32.0 \%$ & $1.8 \%$ & $50.7 \%$ & $4.6 \%$ & $4.5 \%$ & $6.4 \%$ \\
\hline \multirow{2}{*}{\multicolumn{2}{|c|}{ Total }} & Count & 5009 & 438 & 7597 & 723 & 852 & 1173 \\
\hline & & Percentage & $31.7 \%$ & $2.8 \%$ & $48.1 \%$ & $4.6 \%$ & $5.4 \%$ & $7.4 \%$ \\
\hline
\end{tabular}

Note: The highlighted numbers are addressed in the text. 
TABLE 4. Comparing the frequencies of different window status by the hour of observation.

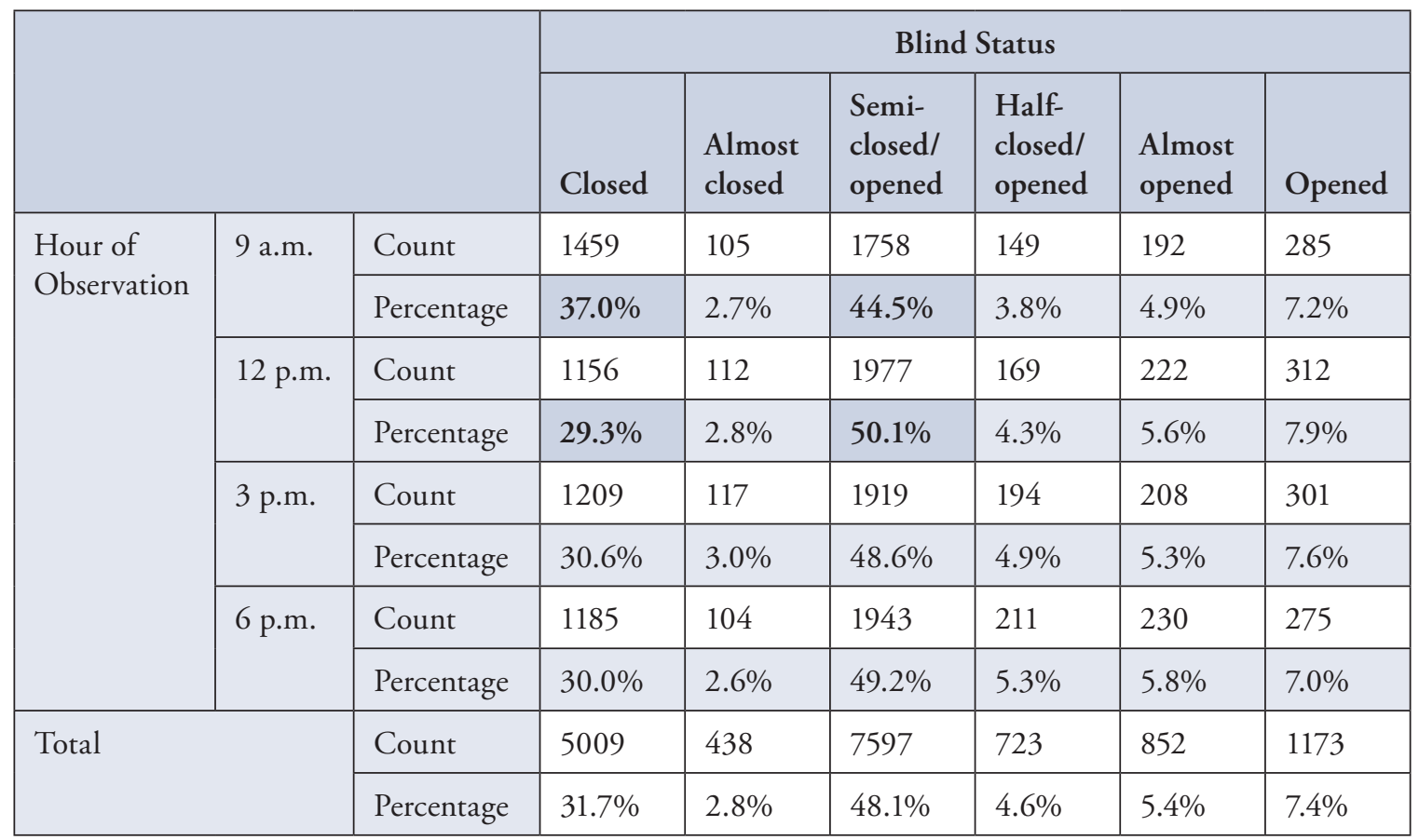

Note: The highlighted numbers were addressed within the text.

Table 4 shows the descriptive results for the blind status when accounting for the hour of observation. The results showed that at 9:00 am, almost 37\% of the blinds were closed. At 12:00 pm, 3:00 pm, 6:00 pm, the percentage of the closed blinds dropped to almost 30\%, while the other categories of the blinds' status showed a slight increase at 12:00 pm, 3:00 pm, and 6:00 pm. It was particularly noticed that the decrease in the number of the closed blinds was associated with an increase in the semi-closed/open blinds.

Table 5 shows the weather conditions, including temperature, sky conditions, humidity, wind speed, and direction. Table 6 shows the descriptive results for the blinds' status when accounting for the fifth independent variable, weather conditions. When it was sunny, $31.6 \%$ of the blinds were closed, and $6.7 \%$ were open, while $49.9 \%$ were semi-closed/open. When it was mostly sunny, $32.2 \%$ of the blinds were closed, and $6.6 \%$ were open, while $47.5 \%$ were semiclosed/open. When it was partly cloudy, $31.6 \%$ of the blinds were closed, and $8.1 \%$ were open, while $47.3 \%$ were semi-closed/open. When it was cloudy, $31.7 \%$ of the blinds were closed, and $7.4 \%$ were open, while $48.1 \%$ were semi-closed/open. The results showed no significant difference in the blinds' closing or opening depending on the weather condition.

The following results considered the second dependent variable observed during this study, which was an artificial lighting status. Artificial lighting was noted in 3.5\% of the windows from 9:00 am to 6:00 pm. First, as shown in Table 7, the percentages of the artificial light used in the first, second, third, and fourth floors were 5.4\%, 3.6\%, 2.7\%, and 2.7\%, respectively. Second, as shown in Table 7, the percentages of the artificial light used in the north, south, east, and west orientations were $3.6 \%, 4.5 \%, 0.3 \%$, and $1.3 \%$, respectively. Table 7 shows that the percentages of the artificial light used on Tuesday through Monday were 3.1\%, 5.8\%, 3.9\%, 
TABLE 5. Weather conditions of the duration of the study.

\begin{tabular}{|c|c|c|c|c|c|c|c|}
\hline & & Sky & Temperature & Weather & Wind & Direction & Humidity \\
\hline \multirow{4}{*}{ First day } & 9:00 a.m. & $\mathrm{X}$ & $66^{\circ} \mathrm{F}$ & Sunny & No wind & $\nabla$ & $70 \%$ \\
\hline & 12:00 p.m. & $\mathrm{X}$ & $75^{\circ} \mathrm{F}$ & Sunny & No wind & $\downarrow$ & $42 \%$ \\
\hline & 3:00 p.m. & $\mathrm{X}$ & $78^{\circ} \mathrm{F}$ & Sunny & $6 \mathrm{mph}$ & $\downarrow$ & $37 \%$ \\
\hline & 6:00 p.m. & $\mathrm{X}$ & $78^{\circ} \mathrm{F}$ & Sunny & $7 \mathrm{mph}$ & $\swarrow$ & $42 \%$ \\
\hline \multirow{4}{*}{$\begin{array}{l}\text { Second } \\
\text { day }\end{array}$} & 9:00 a.m. & $\mathrm{X}$ & $68^{\circ} \mathrm{F}$ & Sunny & $8 \mathrm{mph}$ & 4 & $76 \%$ \\
\hline & 12:00 p.m. & $\mathrm{X}$ & $75^{\circ} \mathrm{F}$ & Sunny & $10 \mathrm{mph}$ & 4 & $62 \%$ \\
\hline & 3:00 p.m. & $\mathrm{X}$ & $80^{\circ} \mathrm{F}$ & Sunny & $9 \mathrm{mph}$ & 4 & $56 \%$ \\
\hline & 6:00 p.m. & $\mathrm{X}$ & $80^{\circ} \mathrm{F}$ & Sunny & $7 \mathrm{mph}$ & $\rightarrow$ & $54 \%$ \\
\hline \multirow{4}{*}{$\begin{array}{l}\text { Third } \\
\text { day }\end{array}$} & 9:00 a.m. & $\mathrm{X}$ & $74^{\circ} \mathrm{F}$ & Partly Sunny & $7 \mathrm{mph}$ & $x$ & $71 \%$ \\
\hline & 12:00 p.m. & $\mathrm{X}$ & $78^{\circ} \mathrm{F}$ & Partly Cloudy & $9 \mathrm{mph}$ & $\longleftarrow$ & $71 \%$ \\
\hline & 3:00 p.m. & $\mathrm{X}$ & $81^{\circ} \mathrm{F}$ & Partly Cloudy & $8 \mathrm{mph}$ & 2 & $62 \%$ \\
\hline & 6:00 p.m. & $\mathrm{X}$ & $79^{\circ} \mathrm{F}$ & Partly Sunny & $13 \mathrm{mph}$ & $\downarrow$ & $62 \%$ \\
\hline \multirow{4}{*}{$\begin{array}{l}\text { Fourth } \\
\text { day }\end{array}$} & 9:00 a.m. & $\mathrm{X}$ & $65^{\circ} \mathrm{F}$ & Sunny & $12 \mathrm{mph}$ & $\sim$ & $81 \%$ \\
\hline & 12:00 p.m. & $\mathrm{X}$ & $75^{\circ} \mathrm{F}$ & Sunny & $12 \mathrm{mph}$ & 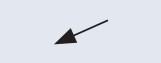 & $50 \%$ \\
\hline & 3:00 p.m. & $\mathrm{X}$ & $77^{\circ} \mathrm{F}$ & Partly Cloudy & $18 \mathrm{mph}$ & $\measuredangle$ & $45 \%$ \\
\hline & 6:00 p.m. & $\mathrm{X}$ & $75^{\circ} \mathrm{F}$ & Sunny & $17 \mathrm{mph}$ & $\measuredangle$ & $43 \%$ \\
\hline \multirow{4}{*}{ Fifth day } & 9:00 a.m. & $\mathrm{X}$ & $63^{\circ} \mathrm{F}$ & Sunny & $8 \mathrm{mph}$ & $\swarrow$ & $65 \%$ \\
\hline & 12:00 p.m. & $\mathrm{X}$ & $77^{\circ} \mathrm{F}$ & Sunny & $13 \mathrm{mph}$ & $\measuredangle$ & $45 \%$ \\
\hline & 3:00 p.m. & $\mathrm{X}$ & $77^{\circ} \mathrm{F}$ & Partly Sunny & $7 \mathrm{mph}$ & $\downarrow$ & $42 \%$ \\
\hline & 6:00 p.m. & $\mathrm{X}$ & $80^{\circ} \mathrm{F}$ & Partly Cloudy & $10 \mathrm{mph}$ & $\swarrow$ & $39 \%$ \\
\hline \multirow{4}{*}{$\begin{array}{l}\text { Sixth } \\
\text { day }\end{array}$} & 9:00 a.m. & $\mathrm{X}$ & $68^{\circ} \mathrm{F}$ & Sunny & No wind & $\downarrow$ & $68 \%$ \\
\hline & 12:00 p.m. & $\mathrm{X}$ & $81^{\circ} \mathrm{F}$ & Sunny & $7 \mathrm{mph}$ & $\rightarrow$ & $41 \%$ \\
\hline & 3:00 p.m. & $\mathrm{X}$ & $84^{\circ} \mathrm{F}$ & Partly Cloudy & $9 \mathrm{mph}$ & $\rightarrow$ & $33 \%$ \\
\hline & 6:00 p.m. & $\mathrm{X}$ & $84^{\circ} \mathrm{F}$ & Sunny & $8 \mathrm{mph}$ & 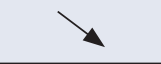 & $32 \%$ \\
\hline \multirow{4}{*}{$\begin{array}{l}\text { Seventh } \\
\text { day }\end{array}$} & 9:00 a.m. & $\mathrm{X}$ & $70^{\circ} \mathrm{F}$ & Sunny & $5 \mathrm{mph}$ & $y$ & $59 \%$ \\
\hline & 12:00 p.m. & $\mathrm{X}$ & $80^{\circ} \mathrm{F}$ & Sunny & $7 \mathrm{mph}$ & 4 & $35 \%$ \\
\hline & 3:00 p.m. & $\mathrm{X}$ & $85^{\circ} \mathrm{F}$ & Sunny & $8 \mathrm{mph}$ & 4 & $34 \%$ \\
\hline & 6:00 p.m. & $\mathrm{X}$ & $85^{\circ} \mathrm{F}$ & Sunny & $5 \mathrm{mph}$ & 4 & $39 \%$ \\
\hline
\end{tabular}

Source: https://www.timeanddate.com/weather/@4991640/historic?month=7\&year=2017

Note: The arrows present the wind direction. 
TABLE 6. Comparing the frequencies of different window status by weather conditions.

\begin{tabular}{|c|c|c|c|c|c|c|c|c|}
\hline & & & \multicolumn{6}{|c|}{ Blind Status } \\
\hline & & & Closed & $\begin{array}{l}\text { Almost } \\
\text { closed }\end{array}$ & $\begin{array}{l}\text { Semi- } \\
\text { closed/ } \\
\text { opened }\end{array}$ & $\begin{array}{l}\text { Half- } \\
\text { closed/ } \\
\text { opened }\end{array}$ & $\begin{array}{l}\text { Almost } \\
\text { opened }\end{array}$ & Opened \\
\hline \multirow{8}{*}{$\begin{array}{l}\text { Weather } \\
\text { Conditions }\end{array}$} & \multirow[t]{2}{*}{ Sunny } & Count & 1426 & 95 & 2250 & 210 & 229 & 302 \\
\hline & & Percentage & $31.6 \%$ & $2.1 \%$ & $49.9 \%$ & $4.7 \%$ & $5.1 \%$ & $6.7 \%$ \\
\hline & \multirow{2}{*}{$\begin{array}{l}\text { Mostly } \\
\text { sunny }\end{array}$} & Count & 909 & 76 & 1339 & 135 & 175 & 186 \\
\hline & & Percentage & $32.2 \%$ & $2.7 \%$ & $47.5 \%$ & $4.8 \%$ & $6.2 \%$ & $6.6 \%$ \\
\hline & \multirow{2}{*}{$\begin{array}{l}\text { Partly } \\
\text { cloudy }\end{array}$} & Count & 2495 & 247 & 3736 & 350 & 427 & 641 \\
\hline & & Percentage & $31.6 \%$ & $3.1 \%$ & $47.3 \%$ & $4.4 \%$ & $5.4 \%$ & $8.1 \%$ \\
\hline & \multirow[t]{2}{*}{ Cloudy } & Count & 179 & 20 & 272 & 28 & 21 & 44 \\
\hline & & Percentage & $31.7 \%$ & $3.5 \%$ & $48.2 \%$ & $5.0 \%$ & $3.7 \%$ & $7.8 \%$ \\
\hline \multirow{2}{*}{\multicolumn{2}{|c|}{ Total }} & Count & 5009 & 438 & 7597 & 723 & 852 & 1173 \\
\hline & & Percentage & $31.7 \%$ & $2.8 \%$ & $48.1 \%$ & $4.6 \%$ & $5.4 \%$ & $7.4 \%$ \\
\hline
\end{tabular}

Note: The highlighted numbers are addressed in the text.

$3.3 \%, 3 \%, 2.6 \%$, and $3.1 \%$, respectively. Table 7 also shows that the percentages of the artificial light used at 9:00 am, 12:00 pm, 3:00 pm, and 6:00 pm were $3.1 \%, 3 \%, 3.1 \%$, and $5 \%$. The percentages of the artificial light used on the sunny, mostly sunny, partly cloudy, and cloudy days were $2.7 \%, 3.4 \%, 4.1 \%$, and $3.2 \%$, respectively (see Table 7 ). Finally, the percentages of the artificial light used when the blinds were closed, almost closed, semi-closed/open, half-closed/ open, almost open, and open were $0 \%, 2 \%, 58 \%$, and $10 \%, 10 \%$, and $19 \%$, respectively.

\subsection{Generalized Linear Mixed Model}

The six categories of the previously identified blinds' status, closed, almost closed, semi-closed/ open, half-closed/open, almost open, and open, were compressed into three categories, closed, closed/open, and open, as shown in Figure 6. The data analysis was performed using generalized linear mixed models with a logit link. The household ID was represented as a cluster of subjects in this study since the data collected represented repeated measurements for windows in the same apartment units.

The random effect for windows was excluded to mitigate estimation problems due to response sparseness in most of the windows observed (see Table 10). Random effects were included in the model to account for dependence in measurements of multiple window observations per apartment. Given the limited number of buildings in the study, the building number was modeled as a fixed effect to account for dependence at that level. However, preliminary analysis revealed that the building number did not significantly affect the occupants' behavior of 
TABLE 7. Counts and percentages of artificial light status by floor level, window orientation, day of observation, the hour of observation, weather conditions, and blind status.

\begin{tabular}{|c|c|c|c|c|}
\hline & & & Artifi & l Light \\
\hline & & & Artificial light off & Artificial light on \\
\hline Floor Level & First floor & Count & 3498 & 198 \\
\hline & & Percentage & $94.6 \%$ & $5.4 \%$ \\
\hline & Second floor & Count & 3887 & 145 \\
\hline & & Percentage & $96.4 \%$ & $3.6 \%$ \\
\hline & Third floor & Count & 3924 & 108 \\
\hline & & Percentage & $97.3 \%$ & $2.7 \%$ \\
\hline & Fourth floor & Count & 3924 & 108 \\
\hline & & Percentage & $97.3 \%$ & $2.7 \%$ \\
\hline Total & & Count & 15233 & 559 \\
\hline & & Percentage & $96.5 \%$ & $3.5 \%$ \\
\hline Window & North & Count & 6315 & 237 \\
\hline Orientation & & Percentage & $96.4 \%$ & $3.6 \%$ \\
\hline & South & Count & 6420 & 300 \\
\hline & & Percentage & $95.5 \%$ & $4.5 \%$ \\
\hline & East & Count & 1174 & 4 \\
\hline & & Percentage & $99.7 \%$ & $0.3 \%$ \\
\hline & West & Count & 1324 & 18 \\
\hline & & Percentage & $98.7 \%$ & $1.3 \%$ \\
\hline Total & & Count & 15233 & 559 \\
\hline & & Percentage & $96.5 \%$ & $3.5 \%$ \\
\hline Day of & First day & Count & 2186 & 70 \\
\hline Observation & & Percentage & $96.9 \%$ & $3.1 \%$ \\
\hline & Second day & Count & 2125 & 131 \\
\hline & & Percentage & $94.2 \%$ & $5.8 \%$ \\
\hline & Third day & Count & 2168 & 88 \\
\hline & & Percentage & $96.1 \%$ & $3.9 \%$ \\
\hline & Fourth day & Count & 2181 & 75 \\
\hline & & Percentage & $96.7 \%$ & $3.3 \%$ \\
\hline & Fifth dy & Count & 2189 & 67 \\
\hline & & Percentage & $97.0 \%$ & $3.0 \%$ \\
\hline & Sixth day & Count & 2197 & 59 \\
\hline & & Percentage & $97.4 \%$ & $2.6 \%$ \\
\hline & Seventh day & Count & 2187 & 69 \\
\hline & & Percentage & $96.9 \%$ & $3.1 \%$ \\
\hline Total & & Count & 15233 & 559 \\
\hline & & Percentage & $96.5 \%$ & $3.5 \%$ \\
\hline
\end{tabular}




\begin{tabular}{|c|c|c|c|c|}
\hline & & & Artifi & l Light \\
\hline & & & Artificial light off & Artificial light on \\
\hline Hour of & 9 a.m. & Count & 3827 & 121 \\
\hline Observation & & Percentage & $96.9 \%$ & $3.1 \%$ \\
\hline & 12 p.m. & Count & 3830 & 118 \\
\hline & & Percentage & $97.0 \%$ & $3.0 \%$ \\
\hline & 3 p.m. & Count & 3827 & 121 \\
\hline & & Percentage & $96.9 \%$ & $3.1 \%$ \\
\hline & 6 p.m. & Count & 3749 & 199 \\
\hline & & Percentage & $95.0 \%$ & $5.0 \%$ \\
\hline Total & & Count & 15233 & 559 \\
\hline & & Percentage & $96.5 \%$ & $3.5 \%$ \\
\hline Weather & Sunny & Count & 4388 & 124 \\
\hline Conditions & & Percentage & $97.3 \%$ & $2.7 \%$ \\
\hline & Mostly sunny & Count & 2725 & 95 \\
\hline & & Percentage & $96.6 \%$ & $3.4 \%$ \\
\hline & Partly cloudy & Count & 7574 & 322 \\
\hline & & Percentage & $95.9 \%$ & $4.1 \%$ \\
\hline & Cloudy & Count & 546 & 18 \\
\hline & & Percentage & $96.8 \%$ & $3.2 \%$ \\
\hline Total & & Count & 15233 & 559 \\
\hline & & Percentage & $96.5 \%$ & $3.5 \%$ \\
\hline Window Status & Opened & Count & 1068 & 105 \\
\hline Original & & Percentage & $91.0 \%$ & $9.0 \%$ \\
\hline & Almost opened & Count & 797 & 55 \\
\hline & & Percentage & $93.5 \%$ & $6.5 \%$ \\
\hline & Half-closed/ & Count & 665 & 58 \\
\hline & opened & Percentage & $92.0 \%$ & $8.0 \%$ \\
\hline & Semi-closed/ & Count & 7272 & 325 \\
\hline & opened & Percentage & $95.7 \%$ & $4.3 \%$ \\
\hline & Almost closed & Count & 427 & 11 \\
\hline & & Percentage & $97.5 \%$ & $2.5 \%$ \\
\hline & Closed & Count & 5004 & 5 \\
\hline & & Percentage & $99.9 \%$ & $0.1 \%$ \\
\hline Total & & Count & 15233 & 559 \\
\hline & & Percentage & $96.5 \%$ & $3.5 \%$ \\
\hline
\end{tabular}


FIGURE 6. Classification of the blind status used in different statistical procedures.
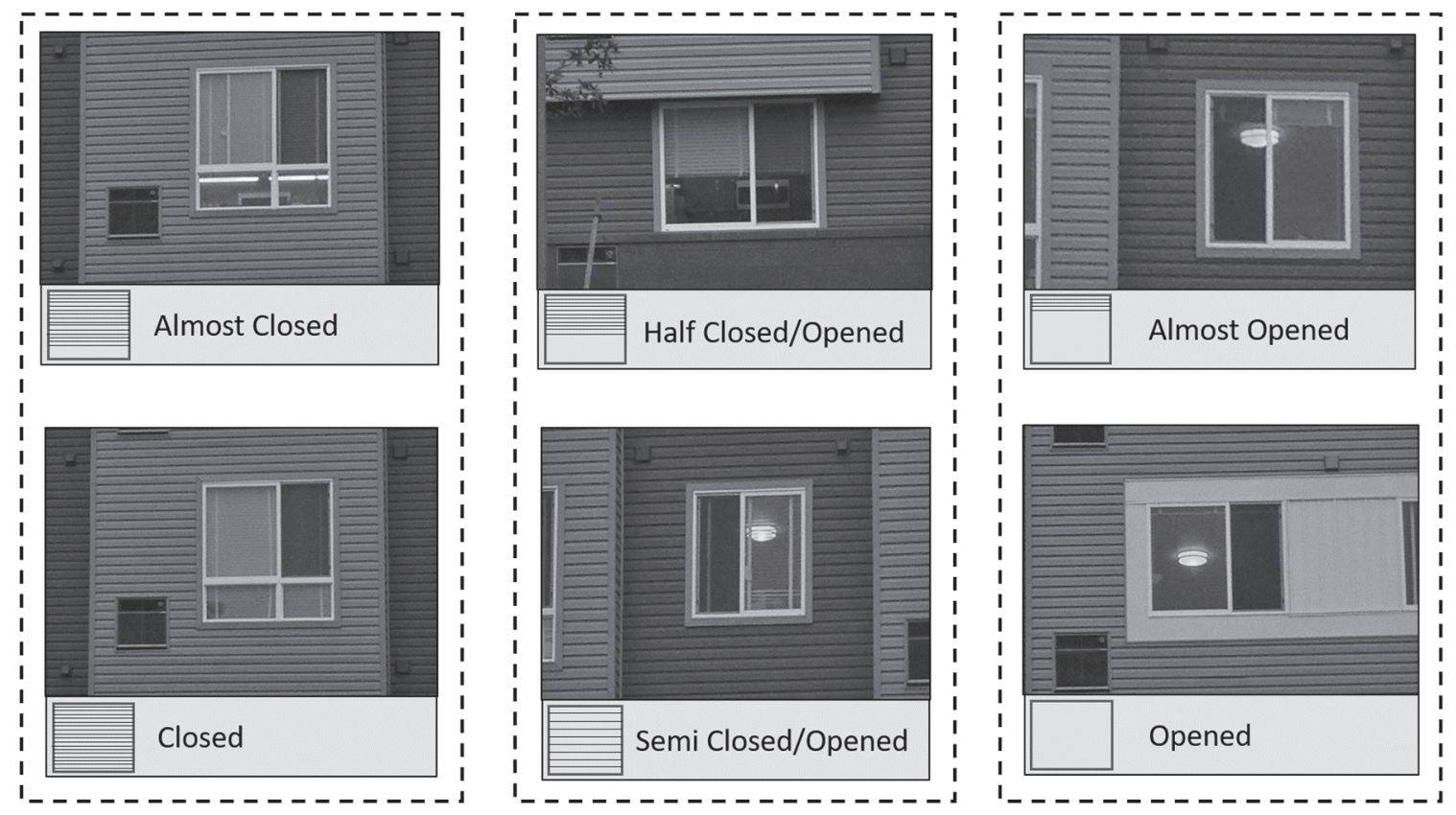

Photo credit by authors.

operating blinds. Therefore, the further analysis considered only random effects for households and fixed effects for orientation and floor levels.

Table 8 shows that the model was $88.0 \%$ accurate in predicting the closed blinds. Furthermore, the model was $91.6 \%$ accurate in predicting the closed/open blinds. Finally, the model was $85.4 \%$ accurate in predicting the open blinds. It is also worth mentioning that there were no non-adjacent predictions - the predicted percentage that the closed window status would be open was $0 \%$, and the predicted percentage that the open window status would be closed was $0.2 \%$.

TABLE 8. The percentage of correct classification of the target blind status was $89.6 \%$.

\begin{tabular}{|l|l|l|l|l|}
\hline \multirow{2}{*}{\multicolumn{2}{|c|}{ Observed }} & \multicolumn{3}{|c|}{ Predicted } \\
\cline { 3 - 6 } Closed & Closed & Closed/Open & Open \\
\cline { 2 - 5 } & Count & 4794 & 653 & 0 \\
\hline \multirow{2}{*}{ Closed/Open } & Count & $88.0 \%$ & $12.0 \%$ & $0.0 \%$ \\
\cline { 2 - 5 } & $\%$ within Observed & 497 & 7620 & 203 \\
\hline \multirow{2}{*}{ Open } & Count & $6.0 \%$ & $91.6 \%$ & $2.4 \%$ \\
\cline { 2 - 5 } & $\%$ within Observed & 4 & 292 & 1729 \\
\hline
\end{tabular}

Note: The highlighted numbers were addressed within the text. 
Table 9 shows that the reference categories for the independent variables, i.e., floor level and window orientations, were the first floor and north orientation, respectively. The fixed effect coefficients for the second, third, and fourth floors were significant for the closed blind status. It means that the odds of the blinds being closed compared to open on the second, third, and fourth floors were about $0.044,0.115$, and 0.130 times that of the first floor. In addition, the fixed effect coefficient for the fourth floor was significant in the case of closed/open blind status. This means that the odds of the blinds being closed/open compared to open on the fourth floor was about 5.457 times that of the first floor.

Considering the independent variable window orientation, the fixed effect coefficient for east orientation was significant in the closed blind status. Specifically, the odds of being closed compared to open in the east orientation was about 19.310 times that of north orientation. The fixed effect coefficients for the south, east, and west orientations were significant in the closed/open blind status. Specifically, the odds of being closed/open compared to open in

TABLE 9. Fixed effects coefficients of the target blind status when the reference category was open.

\begin{tabular}{|c|c|c|c|c|c|}
\hline Blind Status & Model Term & Coefficient & Std. Error & Sig. & Exp(Coefficient) \\
\hline \multirow[t]{9}{*}{ Closed } & Intercept & 3.310 & .6410 & .000 & 27.378 \\
\hline & Fourth Floor & -2.040 & .7557 & .007 & .130 \\
\hline & Third Floor & -2.161 & .7452 & .004 & .115 \\
\hline & Second Floor & -3.113 & .6712 & .000 & .044 \\
\hline & First Floor & $0^{\mathrm{b}}$ & . & . & . \\
\hline & West Orientation & .263 & .6378 & .680 & 1.301 \\
\hline & East Orientation & 2.961 & .7879 & .000 & 19.310 \\
\hline & South Orientation & .404 & .5637 & .473 & 1.498 \\
\hline & North Orientation & $0^{\mathrm{b}}$ & . & . & . \\
\hline \multirow[t]{9}{*}{ Closed/Opened } & Intercept & 3.315 & .5783 & .000 & 27.517 \\
\hline & Fourth Floor & 1.697 & .6687 & .011 & 5.457 \\
\hline & Third Floor & .555 & .7036 & .430 & 1.742 \\
\hline & Second Floor & -.120 & .6645 & .856 & .887 \\
\hline & First Floor & $0^{\mathrm{b}}$ & . & . & . \\
\hline & West Orientation & 1.590 & .5000 & .001 & 4.906 \\
\hline & East Orientation & 3.151 & .6750 & .000 & 23.352 \\
\hline & South Orientation & -1.923 & .4879 & .000 & .146 \\
\hline & North Orientation & $0^{\mathrm{b}}$ & . & . & . \\
\hline
\end{tabular}

Note: The highlighted numbers were addressed within the text. 
TABLE 10. Random effects of the household when comparing open blinds to closed/open and closed.

\begin{tabular}{|l|l|l|l|l|l|l|}
\hline & & & & & \multicolumn{2}{|c|}{$\begin{array}{c}\text { 95\% Confidence } \\
\text { Interval }\end{array}$} \\
\cline { 6 - 9 } Blind Status & Random Effect Block & Estimate & Std. Error & Sig. & Lower & Upper \\
\hline Closed & $\operatorname{Var}$ (Intercept) & 11.012 & 1.852 & .000 & 7.920 & 15.310 \\
\hline Closed/Opened & $\operatorname{Var}$ (Intercept) & 11.035 & 1.538 & .000 & 8.397 & 14.502 \\
\hline
\end{tabular}

the south, east, and west orientations were about 4.906, 23.352, and 0.146 times that of the north orientation.

Table 10 shows that random household effects were significant for both closed and closed/ open blinds when controlling for window orientation and floor level. The significant residual variance at the household level suggests that some additional factors can still be explored to explain occupants' variability in these households. We conducted a descriptive analysis of some of these variables but excluded them from the parametric model to ensure model estimation.

\section{DISCUSSION}

The research results revealed varying levels of correlation between the different categorizations of blind status and the five independent variables: floor level, window orientation, day of observation, the hour of observation, and weather conditions. The results of the Generalized Linear Mixed Model were consistent with the previous descriptive analysis.

When considering the floor level, the percentage of closed blinds on the first floor was higher compared to the second, third, and fourth floors. Additionally, the percentage of open blinds was smaller for the first floor compared to the second, third, and fourth floors. Meaningful odds ratios were observed for the effect of floor level. The odds ratio of closing blinds instead of opening blinds was significantly smaller for the first floor compared to the second, third, and fourth floors.

The association between the floor level and occupants' use of the blinds was significant in this study. This result confirmed other studies reporting that privacy is one of the drivers for residential building occupants' behavior (Bennet et al., 2014; Veitch et al., 2013). Furthermore, the 'floor number' was associated with the status of the blinds. For the six windows on the first floor near the bicycle storage area, only $8 \%$ of the blinds were open, possibly due to privacy concerns.

Furthermore, the total percentages of semi-closed/open blind status remained consistent across all the floor levels, except for the fourth floor, where the odds ratio of closing/opening blinds, instead of opening blinds, was significantly greater compared to the odds of closing/ opening blinds on the other floor levels. The total percentage was the highest for the semi-closed/ open blinds, followed by the closed blinds. The total percentage of open blinds remained the lowest among the three. These observed percentages explain a tendency of occupants of the three buildings to keep their blinds either semi-closed/open or closed.

The window orientation was the second independent variable that correlated strongly with the occupants' blind use. The study compared the total percentages of the blind status of apartments facing the north orientation (parking lot) and facing the south orientation (green 
FIGURE 7. Comparing blind status by floor level.

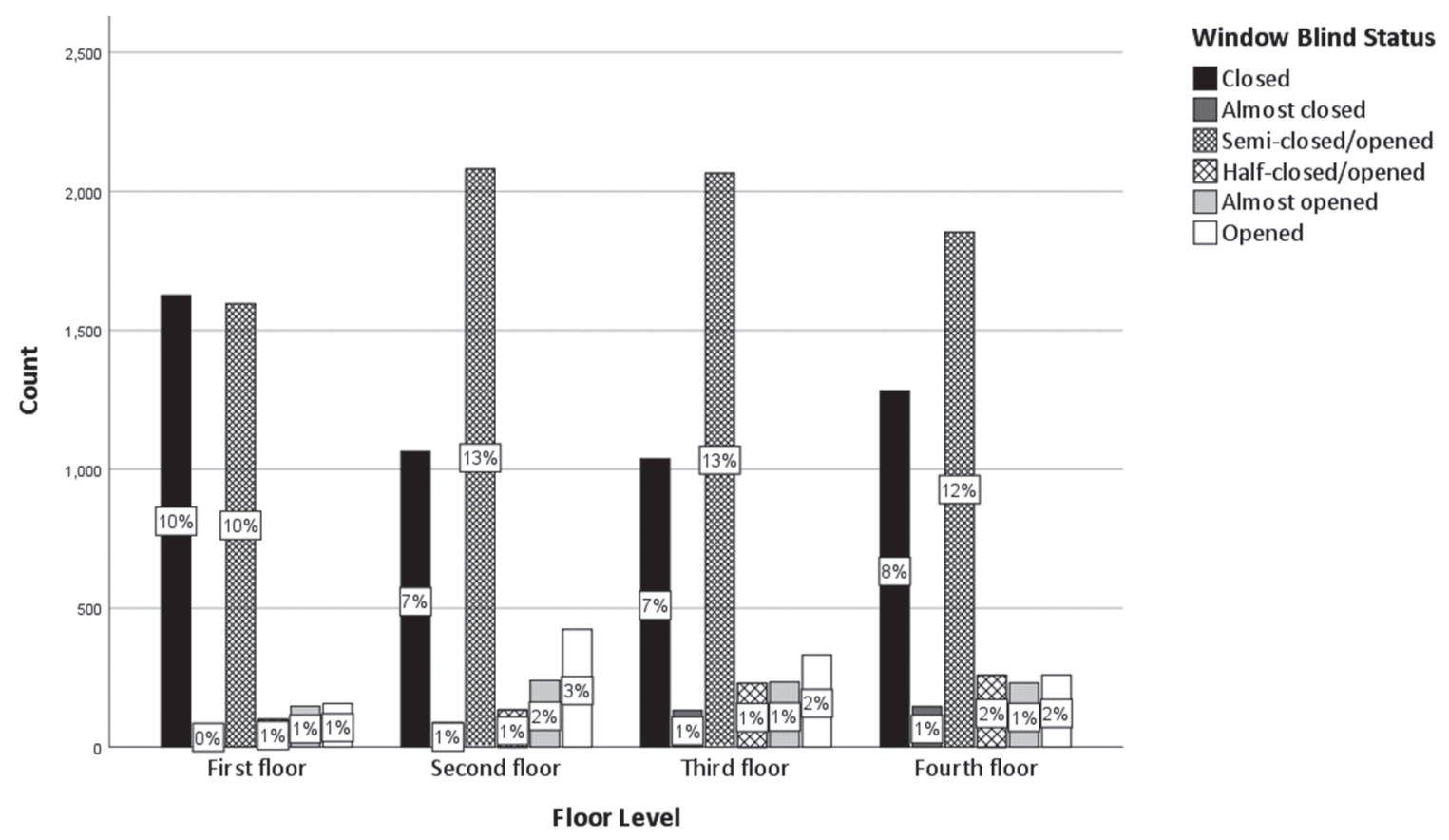

area). Descriptive statistics showed that more blinds were closed in the south façade than in the north façade. Most occupants of apartments facing the north orientation preferred to keep their blinds semi-closed/open. In contrast, the occupants of apartments oriented to the south tended to open their blinds more widely compared to occupants of the apartments oriented to the north. These results confirmed that window orientation influences occupants' use of the blinds, as Pereira and Ramos (2019) indicated.

Comparing closed with open blinds, the odds ratio of closing blinds compared to opening blinds in the east orientation was significant in that the blinds were 19 times more likely to be closed versus open in the east compared to the north orientation. That is a practically significant increase in odds with a p-value of 0.000 . The east, west, and south orientations were significantly different from the north orientation in the open versus closed/open blinds. The odds of closing/ opening the blinds compared to opening blinds were significantly greater for the east and west orientations compared to the north orientation. The odds ratio of closing/opening the blinds compared to opening the blinds was significantly smaller in the south orientation compared to the north orientation. These findings highlight the importance of natural daylight, glare, solar heat gain, and loss. It also emphasizes privacy concerns and the effects of outdoor views on occupants' behavior in adjusting their blinds.

The study's result confirmed the significance of window view and orientation of residential buildings. Residents tend to open the windows when they are facing south orientation or green space. Those factors were emphasized by the LEED (Leadership in Energy and Environmental Design) rating system's indicators. It is assumed that occupants' use of the blinds could be associated with their intention to have more daylight, natural ventilation, and outdoor views.

The last three independent variables, which were the day of observation, the hour of observation, and weather conditions, yielded the same pattern that emerged for the first two 
FIGURE 8. Comparing the categories of the blind status by window orientation.

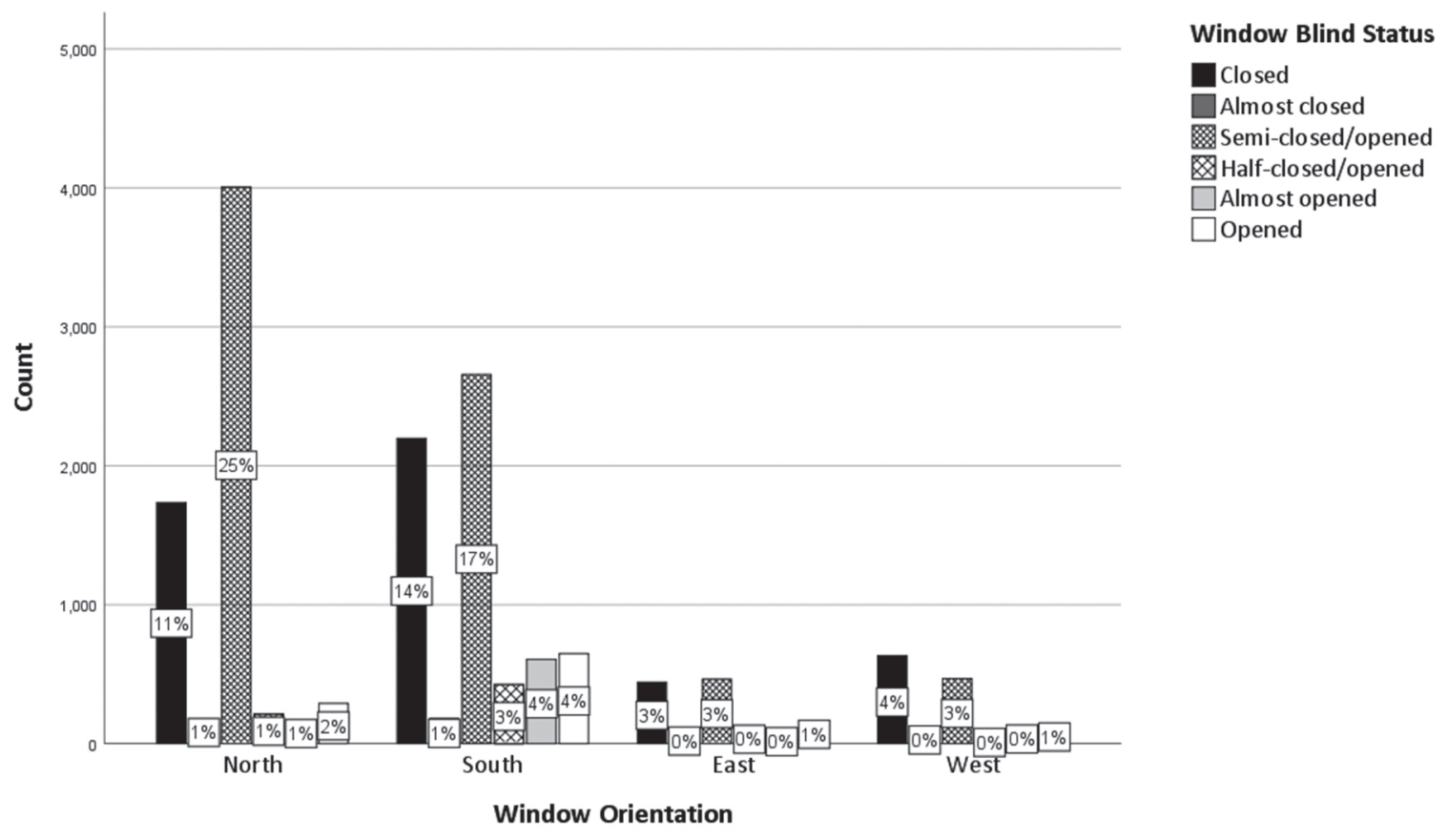

independent variables. Precisely, almost 1/5 of the occupants adjusted their blinds to the semiclosed/open status, while almost $1 / 3$ of them preferred to keep their blinds closed. Finally, less than 1/10 kept their blinds open. Minor changes appeared in the total number of blind status across the seven days of the observation. For example, the percentages of closed blinds were 33.1,

FIGURE 9. Comparing the categories of the blind status by day of observation.

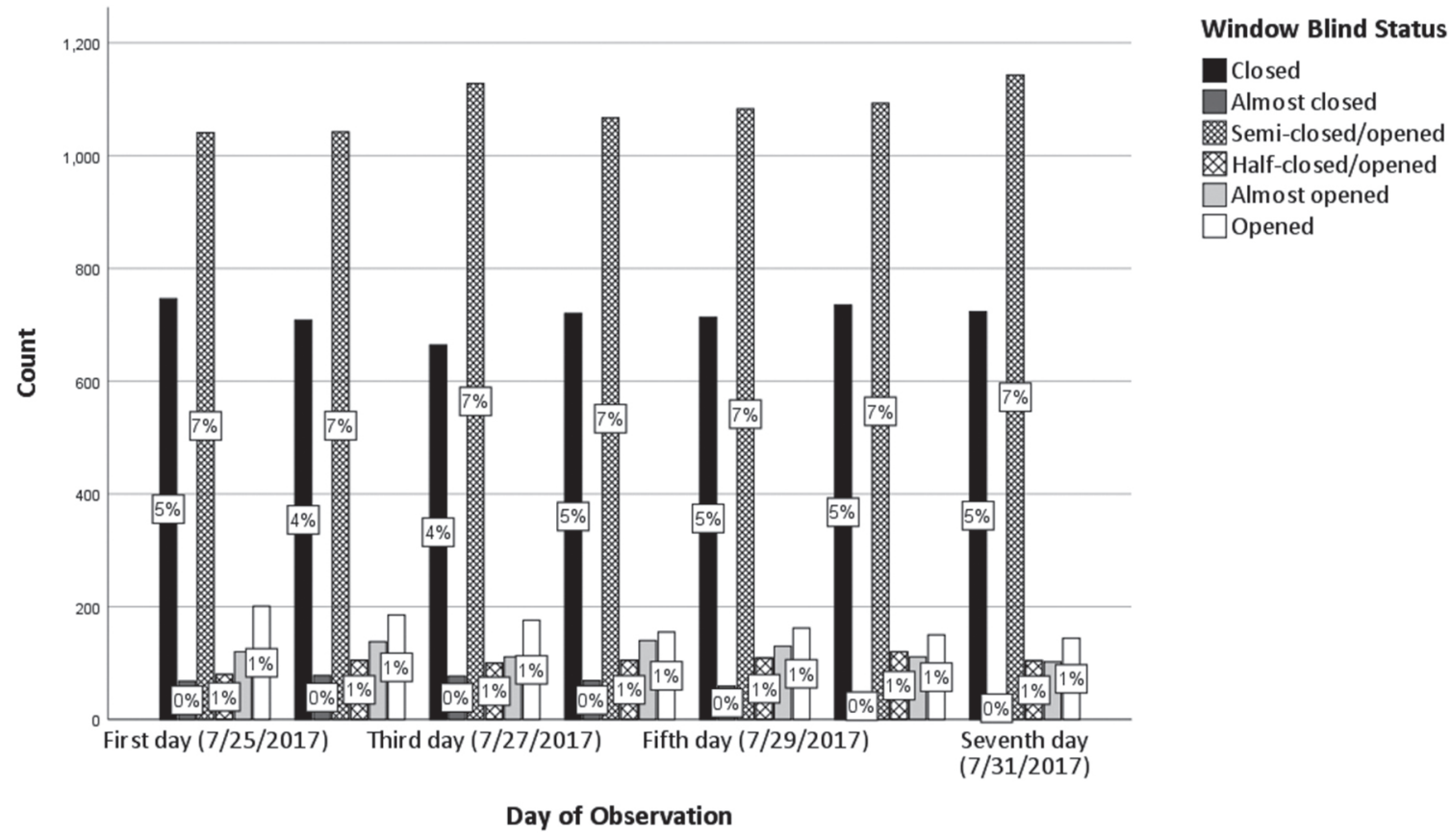


FIGURE 10. Comparing the categories of the blind status by the hour of observation.

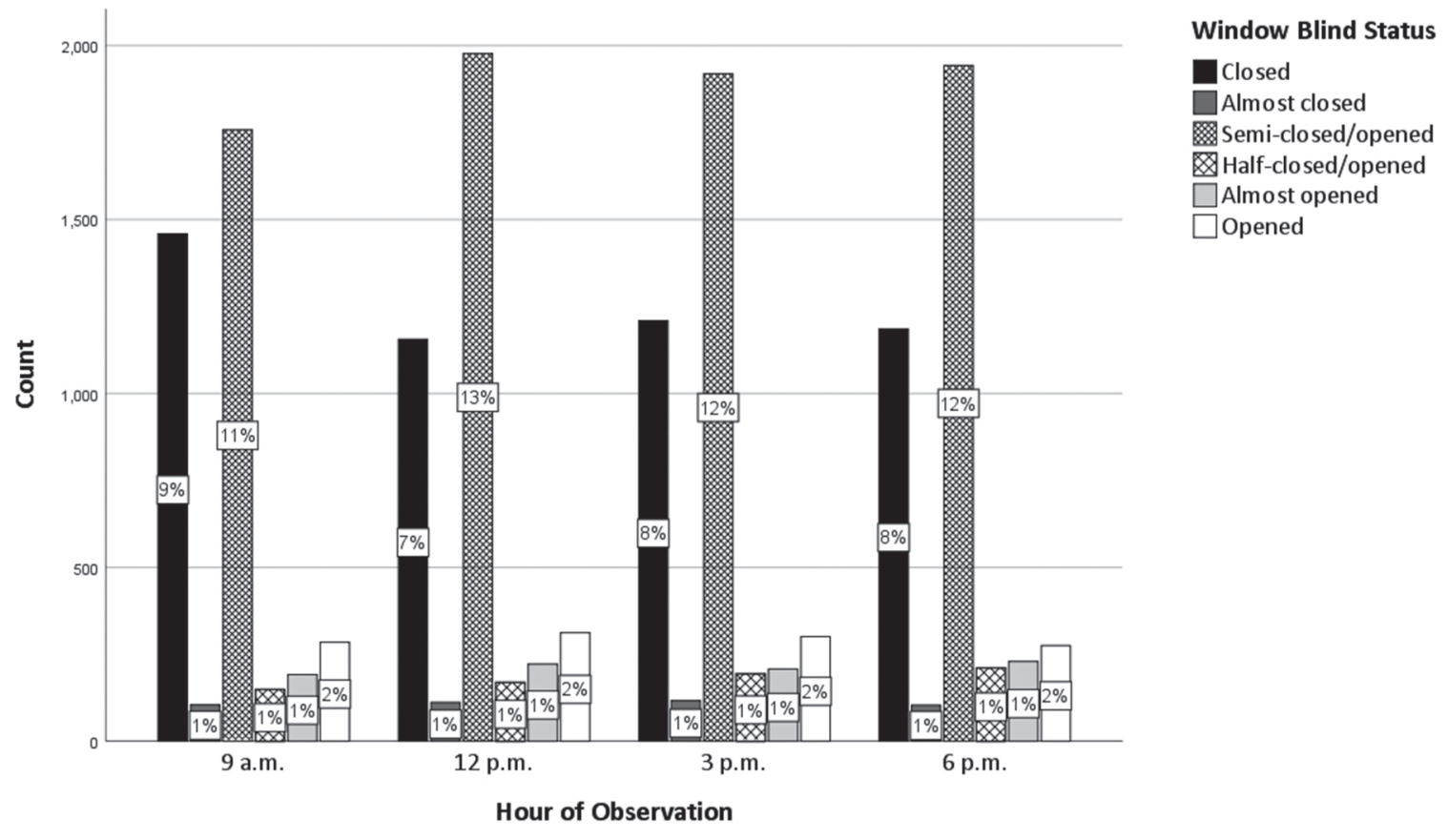

33.4, 29.4, 31.9, 31.6, 32.6, 32.0 on the first, second, third, fourth, fifth, sixth, and seventh day, respectively. This observation can be an indicator that occupants do not adjust their blinds frequently in the short-term. Daily and hourly patterns did not show a significant correlation with weather conditions.

Bennet et al. (2014) reported similar results. They did not report any significant difference in occupants' use of their blinds on the weekends and weekdays. They found that sky conditions were not significantly correlated with the occupants' adjustments of their blinds in the short term. However, other studies showed the seasonal effects in occupants' adjustment of their blinds over the long term (Veitch et al., 2013).

In addition, the fourth independent variable - the hour of observation — showed that at 9:00 a.m., more occupants had their blinds closed, taking into consideration that nighttime was excluded from the observations. As time passed, occupants adjusted their blinds differently according to their needs. This observation suggests that some occupants prefer their blinds closed during nighttime but adjusted them differently during the day to meet their physical and psychological needs. This result was in line with other studies that indicated that at nighttime, darkness and privacy concerns might encourage the residents to keep their blinds closed while they adjust them throughout the rest of the day (Bennet et al. 2014; Veitch et al. 2013). The descriptive statistics indicated that at 12:00 p.m., 3:00 p.m., and 6:00 p.m., almost 30\% of the blinds remained closed. This observation can be due to the occupancy schedule, as the occupants of these spaces were assumed to be at work during this duration.

When studying artificial light use as a dependent variable, $3.5 \%$ of the total number of windows indicated the use of artificial lighting from 9:00 a.m. to 6:00 p.m. Although it may seem like a small percentage, it might suggest that some of the occupants are not satisfied with the visual qualities or the amount of natural light coming through the observed windows. The 
FIGURE 11. Comparing the categories of the blind status by weather conditions.

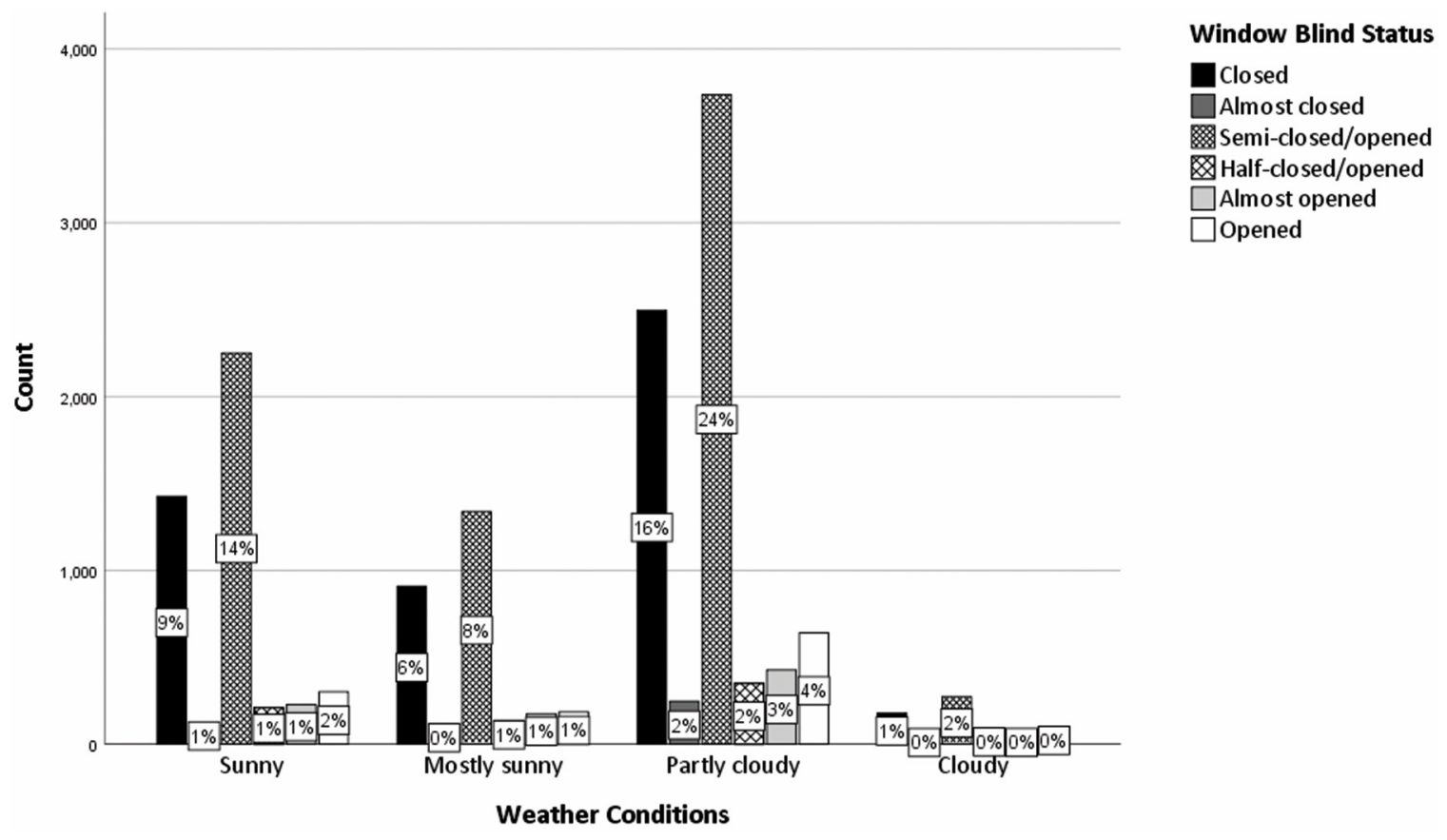

results also showed that the percentage of artificial light use was the highest on the first floor, followed by the second floor and the third and fourth floors.

Regarding the orientation, the results revealed a greater percentage of artificial light being used in windows facing the south compared to the north. In addition, the percentage of artificial light used in windows in the west façade was greater than that in the east façade. These results highlight the importance of window orientation and shed light on the urban features that may affect daylight availability, such as the amount and size of trees and surrounding buildings' height. It is worth mentioning that the amount of artificial light used was consistent across the first three observation times, which are 9:00 a.m., 12:00 a.m., and 3:00 p.m. However, the amount of artificial light used increased in the last hour of observation at 6:00 p.m. This observation indicates that as the number of natural light decreases, the use of artificial light increases, as would be expected. This study's findings also showed that artificial light was used less when it was sunny.

As in the previous studies, the use of the blinds was related to the orientation of windows, window views, the floor level, and the time of the day but not the weather. The observations were conducted over one week only, so the study could not verify the effects of weather conditions on the use of the blinds.

\section{CONCLUSIONS AND SUGGESTIONS}

This research aimed to identify spatial and temporal explanatory variables that correlate with the occupants' use of blinds and determine whether those variables are related to the design of the building and the surrounding site. This study employed a quantitative approach to analyze 
the patterns of blinds use in relation to the buildings' site. Using observations as the major data collection method, this study analyzed the data using descriptive statistics and a generalized linear mixed model with a logit link.

The results showed the importance of the connection between the building and site design and identified the effects of the building and site design on the occupants' adjustment of their blinds. Most occupants of the residential apartments kept their blinds closed or semi-closed/ open. Some occupants kept their blinds semi-closed/open throughout the entire observation period. It was also clear that the windows' orientation, window views, and floor level of the apartment units were correlated with the blinds' use. The results also support that the firstfloors' privacy and views from the window should be fully considered. These findings proved that occupants' use of the blinds reflects their individual preferences, building features, and surrounding environments.

Although only a few studies have discussed the differences in the use of blinds in residential versus commercial buildings, this study showed that occupants in residential buildings adjust their blinds differently compared to occupants of commercial buildings. Commercial building studies showed that occupants tended to open their blinds more in north-oriented windows compared to the south-oriented windows (Pigg et al., 1995). On the other hand, some studies showed that residential building occupants tended to close the blinds on the north-oriented windows more often compared to the commercial occupants. The studies referred to privacy as the main driver of the blinds' different use among commercial building users (Bennet et al., 2014).

The current study focused mainly on observations. Future studies may increase the number of observations collected and replicate the study in different seasons. Additionally, a self-reporting method, such as a survey, can complement the information of observational studies. Collecting more data about the occupants could further clarify some of the occupants' behaviors related to their use of blinds. Other monitoring techniques can also be used to collect data relevant to occupant behaviors, energy consumption, and interior design. In addition, energy simulation software, including daylight simulation, can be used to examine if their results correlate with the results discussed in this study. Finally, comprehensive residential occupant models could be developed and incorporated in building energy tools to increase residential buildings' predicted energy performance accuracy.

This observational study had some limitations. The buildings were newly constructed in 2016, and the study took place in the summer. Accordingly, a few apartment units might have been vacant at the observation time, but the exact vacancy was not counted. Another limitation is that the data were not collected at night because it was difficult to see the blinds. In terms of interior lighting, it was impossible to know whether artificial light was used in apartments with closed blinds. Only floor level and window orientation were included in the generalized linear mixed model. This selection helped us better control the number of variables that could influence the occupant's behavior in operating their blinds.

\section{ACKNOWLEDGMENTS}

This work was supported by the Michigan State University Environmental Science and Policy Program (ESPP) and Residential and Hospitality Services (RHS). In addition, statistical consultation was provided by the Center of Statistical Training and Consulting (CSTAT) at Michigan State University. 


\section{REFERENCES}

Bennet, I., O'Brien, W., \& Gunay, H. B. (2014). Effect of Blind Use in Residential Buildings: Observation and Simulation Study. Ibpsa-Fr 2014. Retrieved from http://www.ibpsa.org/proceedings/eSimPapers/2014/3A.3.pdf

Boyce, P. R. (1980). Observations of the manual switching of lighting. Lighting Research \& Technology, 12(4), 195-205. Retrieved from https://doi.org/10.1177/096032718001200403

Brambley, M. R., Kennedy, E. M., \& Penner, S. S. (1981). Fenestration devices for energy conservation-IV. Field study. Energy, 6(9), 883-894. Retrieved from https://doi.org/10.1016/0360-5442(81)90060-8

Brambley, M. R., \& Penner, S. S. (1979). Fenestration devices for energy conservation-II. Fenestration performance during the heating season. Energy, 4(1), 27-31. Retrieved from https://doi.org/10.1016/0360-5442(79)90049-5

Brambley, M. R., \& Penner, S. S. (1979). Fenestration devices for energy conservation-I. Energy savings during the cooling season. Energy, 4(1), 1-25. Retrieved from https://doi.org/10.1016/0360-5442(79)90050-1

Carlucci, S., Lobaccaro, G., Li, Y., Lucchino, E. C., \& Ramaci, R. (2016). The effect of spatial and temporal randomness of stochastically generated occupancy schedules on the energy performance of a multiresidential building. Energy and Buildings, 127, 279-300. Retrieved from https://doi.org/10.1016/j.enbuild.2016.05.023

Center of Disease Control and Prevention (CDC). Indoor Air Quality. (2016). Retrieved October 10, 2016, from https://www.cdc.gov/healthyhomes/bytopic/airquality.html

Dubois, M. C. (1997). Solar shading and building energy use. Lund University, 960480, 1-118. Retrieved from http://citeseerx.ist.psu.edu/viewdoc/download?doi=10.1.1.595.7355\&rep=rep1\&type=pdf

Environmental Protection Agency (EPA), \& National Institute for Occupational Safety and Health (NIOSH) (1998). Building Air Quality—Action Plan. Retrieved October 11, 2018, from https://www.cdc.gov/niosh/ docs/98-123/

Foster, M., \& Oreszczyn, T. (2001). Occupant control of passive systems: the use of Venetian blinds. Building and Environment, 36(2), 149-155. Retrieved from https://doi.org/10.1016/S0360-1323(99)00074-8

Hong, T., Oca, S. D., Turner, W. J. N., \& Taylor-lange, S. C. (2015). An Ontology to Represent Energy-related Occupant Behavior in Buildings Part I: Introduction to the DNAs Framework. Building and Environment, 92(May), 764-777. Retrieved from https://doi.org/10.1016/j.buildenv.2015.02.019

Humbert, S. (2007). UC Berkeley. Int J LCA, (12), 46-57. Retrieved from https://doi.org/10.1016/ S0022-4073(03)00152-3

Lindsay, C.T.R. \& Littlefair, P.J. (1992). Occupant use of venetian blinds in offices, Building Research Establishment (BRE), Contract PD233/92, Watford, UK: Garston Library.

Mahdavi, A. (2015). Human ecology and building science: A necessary synthesis. Sustainable human-building ecosystems. The First International Symposium on Sustainable Human-Building Ecosystems, 1-17. Reston, VA: American Society of Civil Engineers. Retrieved from https://doi.org/10.1061/9780784479681.001

O’Brien, W., Kapsis, K., \& Athienitis, A. K. (2013). Manually-operated window shade patterns in office buildings: A critical review. Building and Environment, 60,319-338. https://doi.org/10.1016/j.buildenv.2012.10.003

Pereira, Pedro F., and Nuno MM Ramos. "Occupant behaviour motivations in the residential context-An investigation of variation patterns and seasonality effect." Building and Environment, 148(2019): 535-546. Retrieved from https://doi.org/10.1016/j.buildenv.2018.10.053

Pigg, S., Eilers, M., Reed, J. (1995). Behavioral Aspects of Lighting and Occupancy Sensors in Private Offices: A Case Study of a University Office Building Scott Pigg, Energy Center of Wisconsin Mark Eilers, Independent Consultant John Reed, TecMRKT Works, 161-170. Retrieved from https://aceee.org/files/proceedings/1996/ data/papers/SS96_Panel8_Paper18.pdf

Pletzer, R. K., Jones, J. W., \& Hunn, B. D. (1987). Energy Savings Resulting from Shading Devices on SingleFamily Residences in Austin, Texas. Retrieved from http://hdl.handle.net/1969.1/6484

Reinhart, C. F., \& Voss, K. (2003). Monitoring manual control of electric lighting and blinds. Lighting Research and Technology, 35(3), 243-258. https://doi.org/10.1191/1365782803li064oa

Rubin, A. I., Collins, B. L., \& Tibbott, R. L. (1978). Blinds as a potential energy saver-a case study. NBS Building Science Series, 112, 89. Retrieved from https:/www.ncjrs.gov/pdffiles1/Digitization/64368NCJRS.pdf

Tam, V. W., Almeida, L., \& Le, K. (2018). Energy-related occupant behavior and its implications in energy use: A chronological review. Sustainability, 10(8), 2635. Retrieved from https://doi.org/10.3390/su10082635

Yan, D., O’Brien, W., Hong, T., Feng, X., Burak Gunay, H., Tahmasebi, F., \& Mahdavi, A. (2015). Occupant behavior modeling for building performance simulation: Current state and future challenges. Energy and Buildings, 107, 264-278. Retrieved from https://doi.org/10.1016/j.enbuild.2015.08.032 
United States Energy Information Administration (EIA) Residential Energy Consumption Survey (RECS) (2015). Retrieved October 11, 2018, from http://www.eia.gov/consumption/residential/index.cfm

United States Green Building Council (USGBC) (2013). LEED Reference Guide for Building Design and Construction. U.S. Green Building Council. Washington, DC.

Veitch, Jennifer A.; Mancini, Sandra; Galasiu, Anca D.; Laouadi, A. (2013). Survey on Canadian households' control of indoor climate. Ottawa, Canada: National Research Council Canada. Retrieved from https://doi. org/10.4224/21268895

Zhang, Y., \& Barrett, P. (2012). Factors influencing occupants' blind-control behaviour in a naturally ventilated office building. Building and Environment, 54, 137-147. Retrieved from https://doi.org/10.1016/j. buildenv.2012.02.016 
